\title{
Assessment of the Circulating Tumor Cells and Microsatellite Instability in Colorectal Cancer Patients: Prognostic and Diagnostic Value
}

This article was published in the following Dove Press journal: OncoTargets and Therapy

\author{
Aya Alsayed' \\ Salem E Salem (iD)' \\ Mostafa M El Serafi' \\ Mona $S$ Abdellateif $\left(\mathbb{D}^{2}\right.$ \\ Abdel-Rahman N Zekri ${ }^{3}$ \\ Marwa Mohanad (D) ${ }^{4}$ \\ Abeer A Bahnassy ${ }^{5}$ \\ 'Department of Medical Oncology, \\ National Cancer Institute, Cairo \\ University, Cairo, II 976, Egypt; ${ }^{2}$ Medical \\ Biochemistry and Molecular Biology, \\ Cancer Biology Department, National \\ Cancer Institute, Cairo University, Cairo, \\ I 1976, Egypt; ${ }^{3}$ Molecular Virology and \\ Immunology Unit, Cancer Biology \\ Department, National Cancer Institute, \\ Cairo University, Cairo, II 976, Egypt; \\ ${ }^{4}$ Biochemistry Department, College of \\ Pharmaceutical Sciences and Drug \\ Manufacturing, Misr University for \\ Science and Technology, Giza, 12945, \\ Egypt; ${ }^{5}$ Pathology Department, National \\ Cancer Institute, Cairo University, Cairo, \\ I1976, Egypt
}

Background: Microsatellite instability (MSI) and circulating tumor cells (CTCs) play important roles in the diagnosis, prognosis and management of colorectal cancer (CRC) patients.

Methods: CTCs and MSI were assessed in the blood and representative tumor tissues of 100 CRC patients by flow cytometry (FCM) and PCR amplification. The data were correlated to relevant clinicopathological features of the patients, progression-free survival (PFS) and overall survival (OS) rates.

Results: MSI-high was detected in 44 (44.0\%) patients, MSI-low in 37 (37\%), and microsatellite stable (MSS) in $19(19.0 \%)$ patients $(\mathrm{P}=0.007)$. The baseline CTCs count $(<4$ cells/ $7 \mathrm{~mL}$ blood) was reported in $39 \%$ of the patients, and CTCs $\geq 4$ cells $/ 7 \mathrm{~mL}$ blood in $61 \%$ of the patients $(\mathrm{P}=0.028)$. Improved PFS and OS rates were associated significantly with MSI-high $(\mathrm{P}<0.001)$, decreased CTC levels during the course of treatment $(\mathrm{P}<0.001)$ and posttreatment CTCs $(\mathrm{P}=0.008)$. There was no significant association between MSI-high and PFS or OS in early-stage patients $(\mathrm{P}=0.187$ and $\mathrm{P}=0.187$; respectively); however, it was associated significantly with better PFS and OS in late-stage patients $(\mathrm{P}<0.001)$. Multivariate analysis showed that only a change in serial CTC levels is considered an independent prognostic factor for OS $(\mathrm{P}<0.012)$. Post-treatment CTCs level, serial CTCs level changes during the course of treatment, lymph nodes and distant metastasis were independent prognostic factors for $\mathrm{PFS}(\mathrm{P}<0.001, \mathrm{P}=0.047, \mathrm{P}=0.001$ and $\mathrm{P}<0.001$; respectively).

Conclusion: MSI and CTCs could be used as accurate, reliable and sensitive diagnostic and prognostic biomarkers for CRC patients' survival rates and outcomes.

Keywords: circulating tumor cells, microsatellite instability, colorectal cancer, response to treatment, survival rates

\section{Introduction}

Colorectal cancer (CRC) is the third most common cancer, and the fourth leading cause of cancer-related death worldwide. ${ }^{1}$ The estimated 5-year survival rate in metastatic patients is only $13 \%,{ }^{2}$ and its management usually involves surgical resection of the primary tumor followed by chemotherapy and/or targeted therapy for late disease stage. ${ }^{3}$ Despite the advancement of these treatment strategies, drug resistance still represents a major unresolved issue, and about one-third of the patients who underwent curative surgery for CRC experienced disease recurrence. ${ }^{4,5}$ Therefore, there is an increasing demand to search for biomarkers that can help in identifying these patients and improving their outcomes. In the last
Correspondence: Abeer A Bahnassy Pathology Department, National Cancer Institute, Cairo University, Cairo, Egypt Fax +20223644720

Email chaya2000@hotmail.Com 
few years, liquid biopsies proved to be an easy, rapid, sensitive and minimally invasive way for investigating tumor dynamics, and providing accurate data related to progression, determination of treatment course, evaluation of response, and prediction of survival rates. ${ }^{6}$

Circulating tumor cells (CTCs) are cells that shed from the primary tumor into the circulation and therefore, can invade other organs causing metastasis. ${ }^{7}$ It had been demonstrated that the number of CTCs correlated significantly with patients' response to treatment, progressionfree and overall survival rates in different metastatic solid tumors including breast, prostate and colorectal cancers. ${ }^{8-10}$ However, its applicability has been limited by their paucity (1-10 CTCs/million blood cells in average), as well as by the need of highly experienced personnel and highly sensitive techniques for isolation. ${ }^{11}$

Microsatellite instability (MSI) is caused by mutations in the mismatch repair gene (MMR) with consequential inability to correct DNA damage and/or errors during replication and cell division. Mismatch repair genes are inactivated either as a result of germline mutations in certain genes including MLH1, MSH2, MSH6 and PMS2, or as sporadic promoter hypermethylation of MLH1 gene. ${ }^{12}$ MSI testing is considered the main method for the diagnosis of hereditary nonpolyposis CRC (HNPCC), ${ }^{13}$ and it has also been detected in about $10 \%-15 \%$ of the sporadic CRCs in few studies. ${ }^{14}$ Therefore, it is now recommended to evaluate MSI status in all newly diagnosed CRC cases as a prognostic marker especially for stage II CRC patients, for identifying patients with HNPCC, and also to predict response to immunotherapy in patients with stage IV CRC. ${ }^{15}$

The aim of the current study is to assess the possible diagnostic, prognostic and predictive roles of CTCs and MSI in CRC patients. This will be achieved via correlating the number of CTCs (initially and after treatment) and MSI profile to relevant clinicopathological features of the patients, and to assess their impact on overall and progression-free survival rates of the studied patients.

\section{Methods}

This prospective cohort study included 100 wellcharacterized CRC patients who were diagnosed and treated at the National Cancer Institute (NCI), Cairo University during the period from 2012 to 2013.

The eligibility criteria for the recruited patients were 1) aged from 18 to 75 years; 2) histologically confirmed carcinoma of the colon or rectum; 3) all stages were allowed; 4) newly diagnosed CRC patients, with no previous history of malignancy or chemotherapy; 5) received their treatment at NCI, Cairo University. Patients included in the study were assessed regularly for complete medical history, physical examination, laboratory and radiological evaluation according to the NCI, Egypt guidelines.

The study protocol was approved by the ethical committee of the NCI, Cairo University, which was in accordance with the 2011 declaration of Helsinki. A written informed consent was obtained from all participated patients and control subjects prior to enrolment in the study.

\section{Detection and Enumeration of CTCs}

From each patient or control subject, $7 \mathrm{~mL}$ blood was obtained in a sterile, plastic, $15-\mathrm{mL}$ falcon tubes. The samples were transferred immediately to the tissue culture and cytogenetics unit, pathology department, NCI, Cairo University, for detection and enumeration of circulating tumor cells (CTCs). Three blood samples were isolated from each patient for enumeration of CTCs. Baseline CTC was assessed either before surgery or immediately after surgery in stages I, II and III, and before starting palliative chemotherapy in metastatic setting. The second was assessed after 1 month of treatment, while the post-treatment CTC was assessed after 3 months of adjuvant chemotherapy or 3 months of palliative treatment in a metastatic setting. Enumeration of CTCs was done by flow cytometry (FCM) according to the standard protocols. In brief, the mononuclear cells were separated by gradient density centrifugation using Ficoll-Hypaque 1077 (Sigma). The cells were double stained by CK-19- FITC (positive selection, epithelial marker) and CD45 (negative selection, lymphocyte marker; Miltenyi Biotec, MACS, Germany) according to manufacturers' protocols.

The separated cells $(\mathrm{CK}+/ \mathrm{CD} 45$ - cells $)$ were then washed by phosphate buffered saline (PBS), recentrifuged and re-suspended in 5-10 mL PBS for enumeration of CTCs. For each case 10,000 to 30,000 cells were acquired by FCM (Facscalibur, BD Bioscience, USA) using the Cell Quest software. ${ }^{16}$

Serial CTCs change was also assessed through subtracting the count of baseline CTCs from the posttreatment CTCs for each patient.

\section{Detection of Microsatellite Instability (MSI)}

Formalin-fixed, paraffin-embedded tissue (FFPETs) blocks were obtained from the CRC tissues of patients underwent surgery in the surgical unite of the NCI, Cairo University. 
The control samples were obtained from the adjacent normal tissues. Five to eight sections $(4 \mu \mathrm{m}$ each) were obtained from each FFPETs block of the tumor and normal control tissues, they were cut onto a $2-\mathrm{mL}$ plastic, sterile Eppendorf tubes for assessment of MSI.

DNA was extracted from the tumor and normal tissue sections from each patient, and amplified using the MSI analysis system, which is a fluorescent PCR-based assay (Promega, cat.no.MD1641). According to this assay, allelic profiles of certain microsatellite markers were compared in the normal and tested samples. Alleles that were present in the test sample but not in the corresponding normal samples indicated MSI. It included fluorescent-labeled primers for coamplification of seven MSI markers including five mononucleotide repeat markers (BAT-25, BAT-26, NR-21, NR-24 and MONO-27) and two pentanucleotide repeat markers (Penta $\mathrm{C}$ and Penta D). The mononucleotide markers were used for MSI determination, and the pentanucleotide markers were used to detect the potential sample mix-up and/or contamination. Internal lane size standards were added to the PCR samples to assure accurate sizing of the alleles, and to adjust for run-to-run variation. The PCR products were separated by capillary electrophoresis using 3100-Avant Genetic Analyzer, and the output data were analyzed by GeneMapper $^{\circledR}$ Analysis Software to determine MSI status. ${ }^{12,17}$ MSI was classified as follows: samples with MSI $\geq 2$ of the mono-nucleotide repeats (MNMs) are designated MSI-high, samples with MSI in one of the MNMs are designated MSI-low, and samples with no MSI in any of the MNMs are designated MSS.

\section{Statistical Analysis}

Data analysis was performed using a statistical software package (SPSS Inc version 22.0; Chicago, IL, USA). The association between MSI and/or CTCs count and the relevant clinic-pathological characteristics of the patients was done with Fischer's exact test. MannWhitney and Kruskal-Wallis test were used to assess the association between the CTCs count and the clinicpathological characteristics of the patients. Comparison between pre-treatment and post-treatment CTCs count was done using paired $t$ test. The association between the tested markers (MSI and CTCs) with survival was analyzed by Kaplan-Meier plot and Log rank test. Univariate and multivariate survival analyses were performed using the Cox proportional hazard model. All $\mathrm{P}$ values were two-tailed, $\mathrm{P}$ value $<0.05$ was considered as statistically significant.

\section{Results}

\section{Patients' Characteristics}

The current study included 100 CRC patients. The mean age of the patients was $46.2 \pm 14.2$ (range, $17-73$ years). Forty-four patients were males (41\%), and 59 patients were females (59\%). Twelve patients (12\%) had Diabetes mellitus (DM), 13 (13\%) had blood hypertension, and 15 patients $(15 \%)$ had a positive family history for CRC. Thirty-seven patients $(37 \%)$ presented with early tumor stage (I-II), and $36(63 \%)$ presented with late disease stage (III-IV). Most of the patients 75 (75\%) had tumor grade I-II, and 25 patients (25\%) had tumor grade III. The majority of the patients $82(82 \%)$ had adenocarcinoma, while the remaining $18 \%$ had mucinous adenocarcinoma. There were 29 (29\%) patients who had distant metastasis (Table 1).

\section{Management of the Patients}

Eighty-one patients $(81.0 \%)$ underwent surgical resection of their tumors, with the right hemicolectomy was the most performed type of surgery in $25 / 81(30.8 \%)$ of the cases. Chemotherapy was given either alone or concomitant with radiotherapy as a neoadjuvant treatment to 22 patients $(22 \%)$. Whereas adjuvant treatment including chemotherapy and/or radiotherapy was given to 57 patients (57\%). The median duration of adjuvant chemotherapy was 5 months (range 0.5 to 10.0 months). Twenty-nine percent of the cases received chemotherapy as a palliative treatment in patients with metastatic tumors, and 65 cases (65\%) received oxaliplatin-based chemotherapy followed by fluoropyrimidine-based chemotherapy (Table 1).

\section{Assessment of MSI Level in Colorectal Cancer Patients}

Microsatellite instability (MSI) was assessed in all studied patients and accordingly 37 patients (37\%) patients had MSI-low, 19 (19.0\%) patients had MSS, and 44 (44.0\%) patients had MSI-high ( $\mathrm{P}=0.007$, Figure 1A).

\section{Assessment of CTC Levels in Colorectal Cancer Patients}

The baseline CTCs count was lower than 4 cells $/ 7 \mathrm{~mL}$ blood in $39(39 \%)$ patients, and equal or more than 4 cells $/ 7 \mathrm{~mL}$ blood in $61(61 \%)$ patients $(\mathrm{P}=0.028)$. The post-treatment CTCs count was lower than 4 cells $/ 7 \mathrm{~mL}$ blood in $61(61 \%)$ patients, and more than 4 cells $/ 7 \mathrm{~mL}$ blood in 39 (39\%) patients $(\mathrm{P}=0.028)$. The mean count of CTCs before treatment was 
Table I Clinico-Pathological Characteristics of the Assessed Colorectal Cancer Patients $(n=100)$

\begin{tabular}{|c|c|}
\hline Characteristics & Patients, n (\%) \\
\hline \multicolumn{2}{|l|}{ Age (years) } \\
\hline Mean $\pm S D$ & $46.2 \pm 14.2$ \\
\hline$<46$ & $48(48)$ \\
\hline$\geq 46$ & $52(52)$ \\
\hline \multicolumn{2}{|l|}{ Gender } \\
\hline Male & $4 I(4 I)$ \\
\hline Female & $59(59)$ \\
\hline \multicolumn{2}{|l|}{ Diabetes mellitus } \\
\hline Non-diabetic & $88(88)$ \\
\hline Diabetic & $12(12)$ \\
\hline \multicolumn{2}{|l|}{ Hypertension } \\
\hline Non-hypertensive & $87(87)$ \\
\hline Hypertensive & $13(13)$ \\
\hline \multicolumn{2}{|l|}{ Family history } \\
\hline Absent & $85(85)$ \\
\hline Present & $15(15)$ \\
\hline \multicolumn{2}{|l|}{ T-stage } \\
\hline TI-2 & $24(24)$ \\
\hline T3-4 & $76(76)$ \\
\hline \multicolumn{2}{|l|}{ Stage } \\
\hline Early (I-II) & $37(37)$ \\
\hline Late (III-IV) & $63(63)$ \\
\hline \multicolumn{2}{|l|}{ Grade } \\
\hline I-II & $75(75)$ \\
\hline III & $25(25)$ \\
\hline \multicolumn{2}{|l|}{ Metastasis } \\
\hline Mo & 7II (7I) \\
\hline MI & $29(29)$ \\
\hline \multicolumn{2}{|l|}{ Pathology } \\
\hline Adenocarcinoma & $82(82)$ \\
\hline Mucinous & $18(18)$ \\
\hline \multicolumn{2}{|l|}{ Laterality } \\
\hline Right colon & $34(34)$ \\
\hline Left colon & $3 I(3 I)$ \\
\hline Transverse colon & $4(4)$ \\
\hline Rectum & $3 I(3 I)$ \\
\hline \multicolumn{2}{|l|}{ Treatment } \\
\hline Adjuvant & $57(57)$ \\
\hline Neo-adjuvant & $22(22)$ \\
\hline Palliative chemotherapy & $29(29)$ \\
\hline Radiotherapy & $10(10)$ \\
\hline
\end{tabular}

(Continued)
Table I (Continued).

\begin{tabular}{|l|c|}
\hline Characteristics & Patients, n (\%) \\
\hline Type of surgery (8I) & \\
Abdominoperineal resection & $12(14.7)$ \\
Low anterior resection & $11(13.5)$ \\
Left hemicolectomy & $19(23.5)$ \\
Palliative resection & $5(6.1)$ \\
Right hemicolectomy & $25(30.8)$ \\
Transverse colectomy & $9(11.1)$ \\
\hline
\end{tabular}

$8.89 \pm 10.8$ cells $(95 \% \mathrm{CI} ; 6.7-11.04)$, and the median was 5.5 cells with a range of $0-51$ cells. The mean count of CTCs after treatment was $6.26 \pm 8.5(95 \% \mathrm{CI} ; 4.6-7.9)$, and the median was 2.0 with a range of $0-33$ cells $(\mathrm{P}=0.029$, Figure $1 \mathrm{~B})$. The serial CTCs level decreased in $74(74.0 \%)$ patients, and increased in $26(26.0 \%)$ patients $(\mathrm{P}<0.001$, Figure 1C).

\section{Association Between MSI and Clinicopathological Features of the Patients}

The presence of MSI in the assessed tumor samples was associated significantly with tumor stage, as out of all patients with early (I-II) disease stage (37), 24 (64.9\%) patients had MSI-high, 7 (18.9\%) had MSI-low and 6 (16.2\%) had MSS $(\mathrm{P}=0.004)$. MSI was associated significantly with distant metastasis, since 16 (55.2\%) patients out of the 29 patients with distant metastasis were MSI-low, 9 (31.03\%) were MSS and only 4 (13.8\%) patients were MSI-high $(\mathrm{P}<0.001)$. Out of the 44 patients with MSI-high, 40 (90.9\%) patients did not have distant metastasis and four patients had metastatic disease. There was no significant association between MSI and any of the relevant clinicopathological features of the patients including age, gender, family history, presence of diabetes mellitus, hypertension, tumor pathology, grade, or site $(\mathrm{P}>0.05$, Table 2).

\section{Association Between CTCs Count the Clinicopathological Features of the CRC Patients}

The baseline CTCs count did not associate significantly with any of the assessed clinicopathological features of the patients including age, gender, family history, presence of 
A

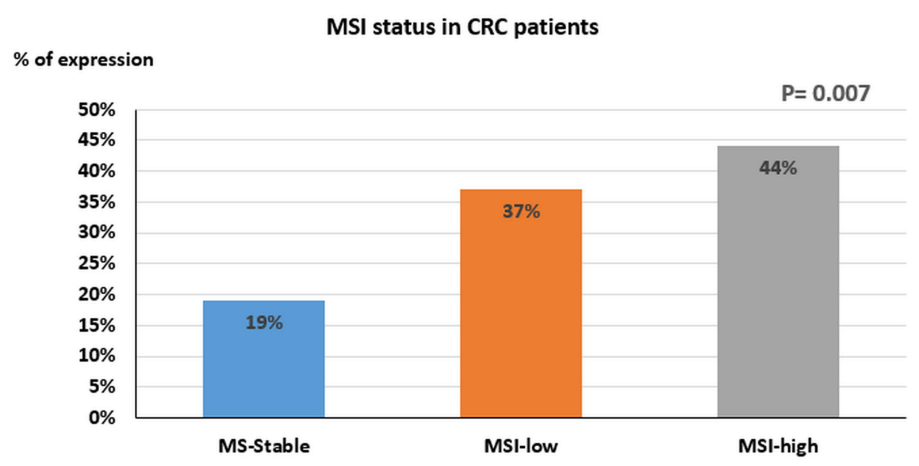

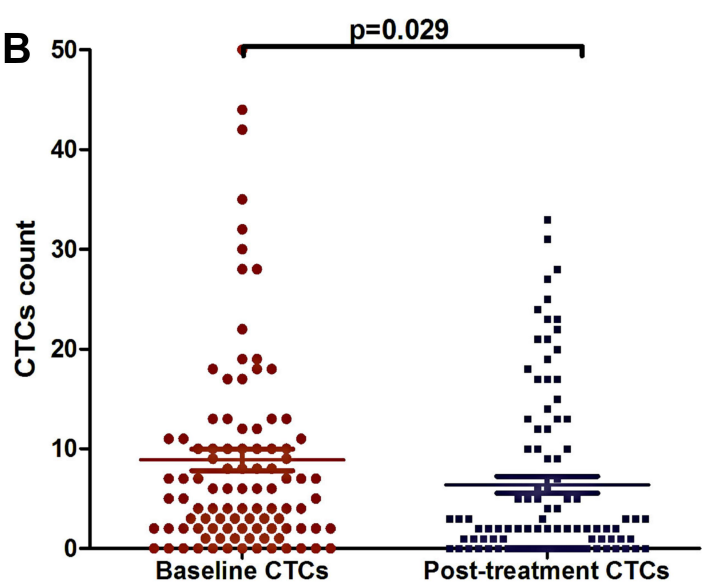

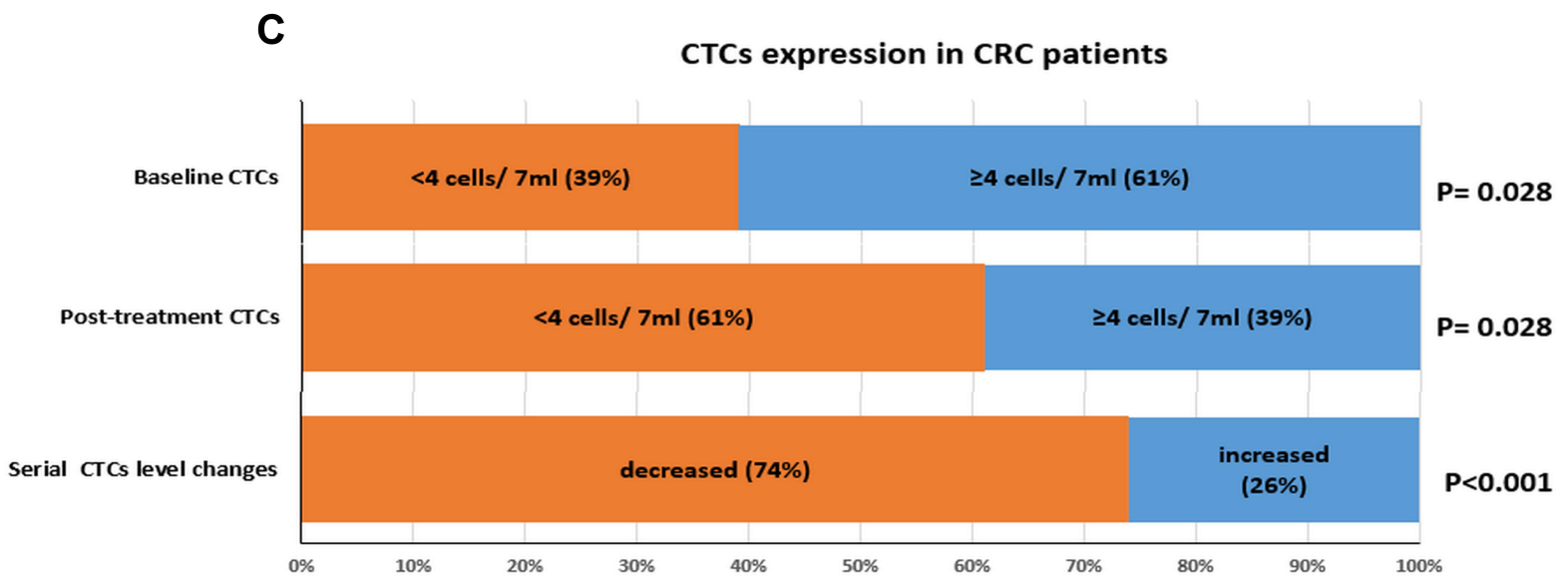

Figure I (A) The expression levels of MSI-high, MSI-low and MSS in colorectal cancer patients, (B) the mean count of CTCs in CRC patients before and after treatment, (C) the expression levels of CTCs (baseline, post-treatment, and serial CTCs change) in the patients.

diabetes mellitus, hypertension, pathological type, tumor grade and stage, tumor site or distant metastasis $(\mathrm{P}>0.05$, Table 3). Similarly, serial CTCs level changes did not associate significantly with the assessed clinicopathological features of the patients except for distant metastasis, since out of the 26 patients with distant metastasis, 15 (57.7\%) showed increased CTC levels during the course of treatment and 11 showed decreased CTC levels $(\mathrm{P}=0.001$, Table 4).

\section{Survival Analysis}

\section{Progression-Free Survival (PFS) Rate}

The median PFS of all assessed patients was 12 months with a cumulative proportion of $90.7 \%, 66.1 \%$ and $33.0 \%$ at 6 months, 1 year and 3 years, respectively. A prolonged PFS rate was associated significantly with the level of posttreatment CTCs $35.3 \%$ in patients with CTCs count $<4$ cells $/ 7 \mathrm{~mL}$ blood compared to $16.9 \%$ in patients with CTCs count $\geq 4$ cells $/ 7 \mathrm{~mL}$ blood $(\mathrm{P}<0.001))$. In addition, PFS was associated significantly with the serial CTC levels during the course of treatment $(34.4 \%$ in patients with decreased CTC levels compared to $11.1 \%$ in patients with increased CTC levels $(\mathrm{P}<0.001)$ ). However, there was no significant association between the baseline CTC levels and PFS rate of the assessed patients (Figure 2A-C). Patients with MSI-high had significantly better PFS rates compared to those with MSI-low /MSS ( $\mathrm{P}<0.001$, Figure 3A). According to the stage of the disease, there was no significant association between MSI and PFS in early-stage patients $(\mathrm{P}=0.187)$; however, in late-stage patients, MSI-high was associated significantly with prolonged PFS compared to those with MSI-low/MSS $(\mathrm{P}<0.001$, Figure $3 \mathrm{C}$ and E, sup. 1).

\section{Overall Survival (OS) Rate}

The cumulative OS rates of the patients were 100\%, 96.1\% and $72.1 \%$ at 6 months, 1 year and 3 years, respectively. The OS rate was associated significantly with the serial CTC levels during the course of treatment $(21.6 \%$ in patients 
Table 2 Association Between MSI and the Clinico-Pathological Features of the CRC Patients

\begin{tabular}{|c|c|c|c|c|}
\hline \multirow[t]{2}{*}{ Characteristics } & \multicolumn{3}{|c|}{ MSI } & \multirow[t]{2}{*}{$P$ value } \\
\hline & Stable $(n=19)$ & MSI-Low $(n=37)$ & MSI-High $(n=44)$ & \\
\hline \multicolumn{5}{|l|}{ Age (years) } \\
\hline$<46$ & $9(47.4)$ & $15(40.5)$ & $24(54.5)$ & 0.45 \\
\hline$\geq 46$ & $10(52.6)$ & $22(59.5)$ & $20(45.5)$ & \\
\hline \multicolumn{5}{|l|}{ Gender } \\
\hline Male & $9(47.4)$ & $15(40.5)$ & $17(38.6)$ & 0.81 \\
\hline Female & $10(52.6)$ & $22(59.5)$ & $27(6 \mid .4)$ & \\
\hline \multicolumn{5}{|l|}{ DM } \\
\hline Non-diabetic & $17(89.5)$ & $31(83.6)$ & $40(90.9)$ & 0.60 \\
\hline Diabetic & $2(10.5)$ & $6(16.2)$ & $4(9.1)$ & \\
\hline \multicolumn{5}{|l|}{ HTN } \\
\hline Non-hypertensive & 17 (89.5) & $31(83.6)$ & $39(88.6)$ & 0.76 \\
\hline Hypertensive & $2(10.5)$ & $6(16.2)$ & $5(11.4)$ & \\
\hline \multicolumn{5}{|l|}{$\mathbf{F H}$} \\
\hline Absent & $16(84.2)$ & $31(83.6)$ & $38(86.4)$ & 0.94 \\
\hline Present & $3(15.8)$ & $6(16.2)$ & $6(13.6)$ & \\
\hline \multicolumn{5}{|l|}{ T-stage } \\
\hline TI-2 & $2(10.5)$ & $9(24.3)$ & $13(29.5)$ & 0.27 \\
\hline T3-4 & $17(89.5)$ & $28(75.7)$ & $31(70.5)$ & \\
\hline \multicolumn{5}{|l|}{ Stage } \\
\hline Early (I-II) & $6(31.6)$ & 7 (I8.9) & $24(54.5)$ & 0.004 \\
\hline III & $4(21.1)$ & $13(35.1)$ & $16(36.4)$ & \\
\hline IV & $9(47.3)$ & $17(45.9)$ & $4(9.1)$ & \\
\hline \multicolumn{5}{|l|}{ Grade } \\
\hline $\mathrm{I}-2$ & 14 (73.7) & $28(75.7)$ & $33(75.0)$ & 0.72 \\
\hline 3 & $5(26.3)$ & $9(24.3)$ & II (25.0) & \\
\hline \multicolumn{5}{|l|}{ Metastasis } \\
\hline MO & $10(52.6)$ & $21(56.8)$ & $40(90.9)$ & $<0.001$ \\
\hline MI & $9(47.4)$ & $16(43.2)$ & $4(9.1)$ & \\
\hline \multicolumn{5}{|l|}{ Laterality } \\
\hline Right & $7(36.8$ & $13(35.1)$ & $\mid 4(3 \mid .8)$ & 0.82 \\
\hline Left & $4(21.1)$ & $10(27.0)$ & $17(36.8)$ & \\
\hline Transverse & $\mathrm{I}(5.3)$ & $\mathrm{I}(2.7)$ & $2(4.5)$ & \\
\hline Rectum & $7(36.8)$ & $13(35.1)$ & II (25.0) & \\
\hline \multicolumn{5}{|l|}{ Pathology } \\
\hline Adenocarcinoma & I8(94.7) & 29(78.4) & $35(79.5)$ & 0.27 \\
\hline Mucinous & $\mathrm{I}(5.3)$ & $8(21.6)$ & $9(20.5)$ & \\
\hline
\end{tabular}

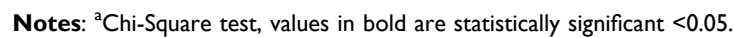

Abbreviation: MSI, microsatellite instability.

with increased CTC levels compared to $43.4 \%$ in patients with decreased CTC levels, $\mathrm{P}<0.001)$. Similarly, OS rate was associated significantly with the post-treatment CTC levels (44.2\% in patients with CTCs count $<4$ cells $/ 7 \mathrm{~mL}$ blood compared to $26.1 \%$ in patients with CTCs count $\geq 4$ cells/
$7 \mathrm{~mL}$ blood $(\mathrm{P}<0.001)$. On the contrary, there was no significant correlation between the baseline CTC level and the OS rate of the assessed patients (Figure 2D-F). Patients with MSI-high had significantly prolonged OS rates compared to those with MSI-low/MSS $(\mathrm{P}<0.001$, Figure 3B). MSI did not 
Table 3 Association Between the Baseline CTCs and Clinic-Pathological Features in CRC Patients

\begin{tabular}{|c|c|c|c|c|c|c|}
\hline \multirow[t]{2}{*}{ Characteristics } & \multirow[t]{2}{*}{$\mathbf{n}$} & \multirow[t]{2}{*}{ Baseline CTCs Count Median (Range) } & \multirow[t]{2}{*}{$P^{a}$ value } & \multicolumn{2}{|c|}{ Baseline CTCs n (\%) } & \multirow[t]{2}{*}{$P$ value } \\
\hline & & & & $<4$ Cells & $\geq 4$ Cells & \\
\hline \multicolumn{7}{|l|}{ Age (years) } \\
\hline$<46$ & 48 & $6.0(0-30)$ & 0.33 & $19(48.7)$ & $29(47.5)$ & $0.9 I^{\mathrm{c}}$ \\
\hline$\geq 46$ & 52 & $5.0(0-51)$ & & $20(51.3)$ & $32(52.5)$ & \\
\hline \multicolumn{7}{|l|}{ Gender } \\
\hline Male & 41 & $5.0(0-30)$ & 0.70 & 15(38.5) & $26(42.6)$ & $0.68^{c}$ \\
\hline Female & 59 & $6.0(0-5 I)$ & & $24(6 \mid .5)$ & $35(57.4)$ & \\
\hline \multicolumn{7}{|l|}{ DM } \\
\hline Non-diabetic & 88 & $5.5(0-50)$ & 0.50 & $34(87.2)$ & $54(88.4)$ & $0.84^{c}$ \\
\hline Diabetic & 12 & $7.0(0-5 I)$ & & $5(12.8)$ & $7(11.6)$ & \\
\hline \multicolumn{7}{|l|}{ Hypertension } \\
\hline Non-hypertensive & 87 & $5.0(0-44)$ & 0.06 & $36(92.3)$ & $5 I(83.6)$ & $0.21^{\mathrm{c}}$ \\
\hline Hypertensive & 13 & $10.0(|-5|)$ & & $3(7.7)$ & $10(16.4)$ & \\
\hline \multicolumn{7}{|l|}{ Family history } \\
\hline Absent & 85 & $6.0(0-51)$ & 0.69 & $31(79.5)$ & $54(88.4)$ & $0.22^{c}$ \\
\hline Present & 15 & $3.0(0-22)$ & & $8(20.5)$ & $7(12.6)$ & \\
\hline \multicolumn{7}{|l|}{ T-stage } \\
\hline $\mathrm{TI}-2$ & 24 & $4.0(0-51)$ & 0.59 & $\mathrm{II}(28.2)$ & $13(2 \mid .3)$ & $0.43^{c}$ \\
\hline T3-4 & 76 & $6.0(0-50)$ & & $28(71.8)$ & $48(78.7)$ & \\
\hline \multicolumn{7}{|l|}{ Stage } \\
\hline Early (I-II) & 37 & $6.0(0-44)$ & 0.74 & $13(33.3)$ & $24(39.3)$ & $0.54^{c}$ \\
\hline Late (III-IV) & 63 & $5.0(0-5 I)$ & & $26(66.7)$ & $37(60.7)$ & \\
\hline \multicolumn{7}{|l|}{ Grade } \\
\hline $\mathrm{I}-2$ & 75 & $5.0(0-51)$ & 0.24 & $30(76.9)$ & $45(73.8)$ & $0.72^{c}$ \\
\hline 3 & 25 & $7.0(0-30)$ & & $9(23.1)$ & $16(26.2)$ & \\
\hline \multicolumn{7}{|l|}{ Metastasis } \\
\hline Mo & 71 & $5.0(0-51)$ & 0.25 & $29(74.4)$ & $42(68.9)$ & $0.55^{c}$ \\
\hline MI & 29 & $7.0(0-50)$ & & $10(25.6)$ & $19(31.1)$ & \\
\hline \multicolumn{7}{|l|}{ Laterality } \\
\hline Right & 34 & $6.0(0-51)$ & $0.53^{\mathrm{b}}$ & $13(33.3)$ & $21(34.4)$ & $0.46^{c}$ \\
\hline Left & 31 & $8.0(0-44)$ & & $12(30.8)$ & $19(31.1)$ & \\
\hline Transverse & 4 & $5.0(4-18)$ & & $0(0.0)$ & $4(6.6)$ & \\
\hline Rectum & 31 & $4.0(0-50)$ & & $14(35.9)$ & $17(27.9)$ & \\
\hline \multicolumn{7}{|l|}{ Pathology } \\
\hline Adenocarcinoma & 82 & $5.0(0-51)$ & $0.28^{\mathrm{a}}$ & $32(82.1)$ & $50(82.0)$ & $1.0^{c}$ \\
\hline Mucinous & 18 & $8.5(0-50)$ & & $7(17.9)$ & II (I8.0) & \\
\hline
\end{tabular}

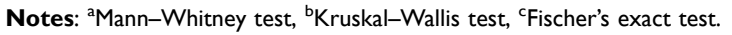

Abbreviation: CTCs, circulating tumor cells.

associate significantly with OS in patients with early-stage tumors $(\mathrm{P}=0.416)$, while with the progression of the disease, MSI-high was associated significantly with better OS rates compared to MSI-low/MSS $(\mathrm{P}<0.001$, Figure 3D and $\mathrm{F}$, sup. 2).

\section{Univariate and Multivariate Survival} Analysis for the Assessed CRC Patients

Univariate survival analysis for the assessed CRC patients showed a significant association between PFS rate and MSI-high $(\mathrm{P}=0.033)$, post-treatment CTCs level $\geq 4$ 
Table 4 Association Between Serial CTCs Level Changes and the Clinicopathological Features of the CRC Patients

\begin{tabular}{|c|c|c|c|c|}
\hline \multirow[t]{2}{*}{ Characteristics } & \multirow[t]{2}{*}{$\mathbf{n}$} & \multicolumn{2}{|c|}{ Serial CTCs Level Changes n(\%) } & \multirow[t]{2}{*}{$p$ value } \\
\hline & & Decrease $(n=74)$ & Increase $(n=26)$ & \\
\hline \multicolumn{5}{|l|}{ Age (years) } \\
\hline$<46$ & 48 & $35(47.3)$ & $13(50.0)$ & $0.82^{\mathrm{a}}$ \\
\hline$\geq 46$ & 52 & $39(52.7)$ & $13(50.0)$ & \\
\hline \multicolumn{5}{|l|}{ Gender } \\
\hline Male & 41 & $28(37.8)$ & $13(50.0)$ & $0.36^{\mathrm{a}}$ \\
\hline Female & 59 & $46(62.2)$ & $13(50.0)$ & \\
\hline \multicolumn{5}{|l|}{ Diabetes Mellitus } \\
\hline Non-diabetic & 88 & $65(87.8)$ & $23(88.5)$ & $1.0^{\mathrm{a}}$ \\
\hline Diabetic & 12 & $9(12.2)$ & $3(11.5)$ & \\
\hline \multicolumn{5}{|l|}{ Hypertension } \\
\hline Non-hypertensive & 87 & $64(86.5)$ & $23(88.5)$ & $1.0^{\mathrm{a}}$ \\
\hline Hypertensive & 13 & $10(13.5)$ & $3(11.5)$ & \\
\hline \multicolumn{5}{|l|}{ Family History } \\
\hline Absent & 85 & $65(87.8)$ & $20(76.9)$ & $0.21^{\mathrm{a}}$ \\
\hline Present & 15 & $9(12.2)$ & $6(23.1)$ & \\
\hline \multicolumn{5}{|l|}{ T-stage } \\
\hline TI-2 & 24 & $14(18.9)$ & $10(38.5)$ & $0.06^{\mathrm{a}}$ \\
\hline T3-4 & 76 & $60(8 I .1)$ & $16(6 \mid .5)$ & \\
\hline \multicolumn{5}{|l|}{ Stage } \\
\hline Early (I-II) & 37 & $3 I(4 I .9)$ & $6(23.1)$ & $0.10^{\mathrm{a}}$ \\
\hline Late (III-IV) & 63 & $43(58.1)$ & $20(76.9)$ & \\
\hline \multicolumn{5}{|l|}{ Grade } \\
\hline $\mathrm{I}-2$ & 75 & $56(75.7)$ & $19(73.1)$ & $0.79^{\mathrm{a}}$ \\
\hline 3 & 25 & $18(24.3)$ & $7(26.9)$ & \\
\hline \multicolumn{5}{|l|}{ Metastasis } \\
\hline MO & 71 & $60(81.1)$ & II (42.3) & $0.00 \mathrm{I}^{\mathrm{a}}$ \\
\hline MI & 29 & $14(18.9)$ & $15(57.7)$ & \\
\hline \multicolumn{5}{|l|}{ Laterality } \\
\hline Right & 34 & $27(36.5)$ & $7(26.9)$ & $0.54^{\mathrm{b}}$ \\
\hline Left & 31 & $20(27.0)$ & II (42.3) & \\
\hline Transverse & 4 & $3(4.1)$ & $\mathrm{I}(3.8)$ & \\
\hline Rectum & 31 & $24(32.4)$ & $7(26.9)$ & \\
\hline \multicolumn{5}{|l|}{ Pathology } \\
\hline Adenocarcinoma & 82 & $62(83.8)$ & $20(76.9)$ & $0.55^{\mathrm{a}}$ \\
\hline Mucinous & 18 & $12(16.2)$ & $6(23.1)$ & \\
\hline
\end{tabular}

Notes: ${ }^{\mathrm{a}}$ Fischer exact test, ${ }^{\mathrm{b}} \mathrm{Chi}$-Square test, values in bold are statistically significant $<0.05$.

Abbreviation: CTCs, circulating tumor cells.

cells $/ 7 \mathrm{~mL}$ blood $(\mathrm{P}<0.001)$, increased CTC level during the course of treatment $(\mathrm{P}<0.001)$, late disease stage III $(\mathrm{P}=0.002)$, distant metastasis $(\mathrm{P}<0.001), \mathrm{LN}$ metastasis $(\mathrm{P}=0.038)$, and the presence of $\mathrm{DM}$ in the assessed patients $(\mathrm{P}=0.012)$. As for OS, significant association was found between OS rate and MSI-high $(\mathrm{P}=0.019)$,
Post-treatment CTCs level $\geq 4$ cells $/ 7 \mathrm{~mL}$ blood $(\mathrm{P}<0.01)$, increased CTC level during the course of treatment $(\mathrm{P}<0.001)$, late disease stage III $(\mathrm{P}=0.029)$, advanced tumor grade $3(\mathrm{P}=0.028)$, and distant metastasis $(\mathrm{P}=0.002)$.

In multivariate logistic regression, only serial CTCs level change was independent prognostic factors for OS 

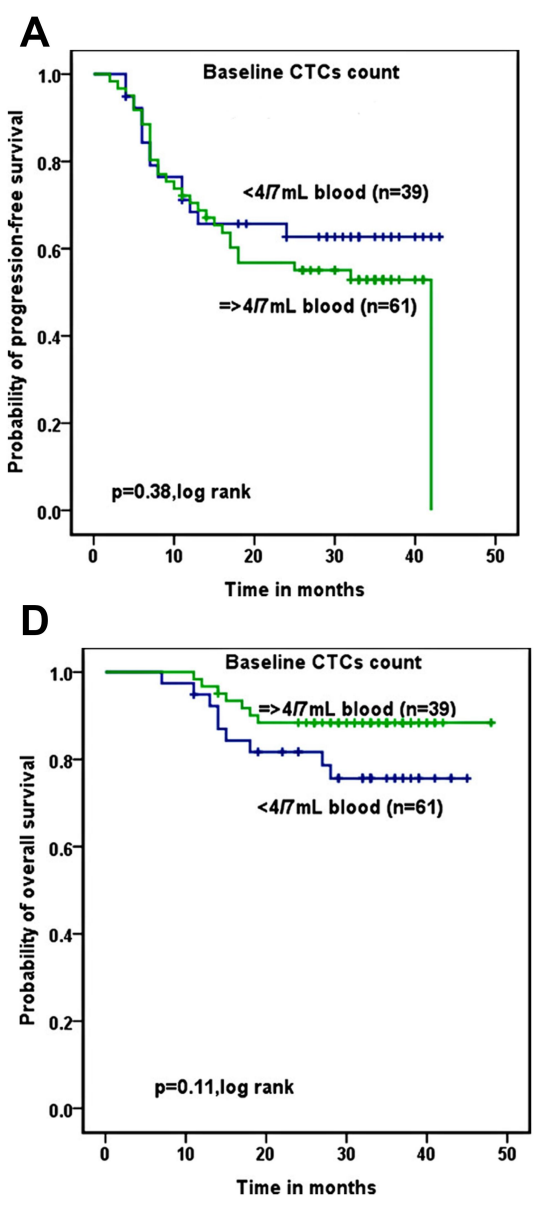

B

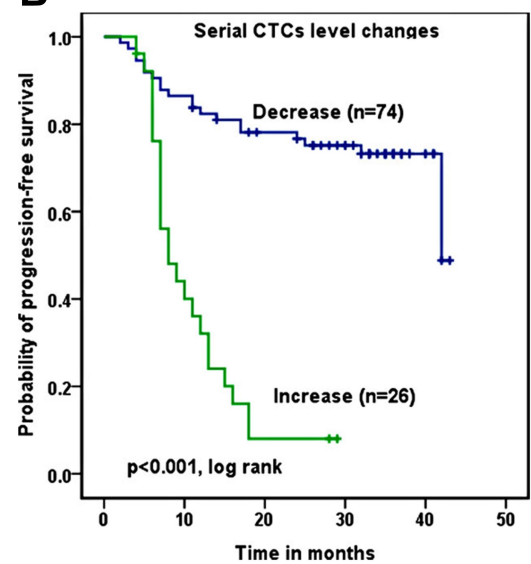

E

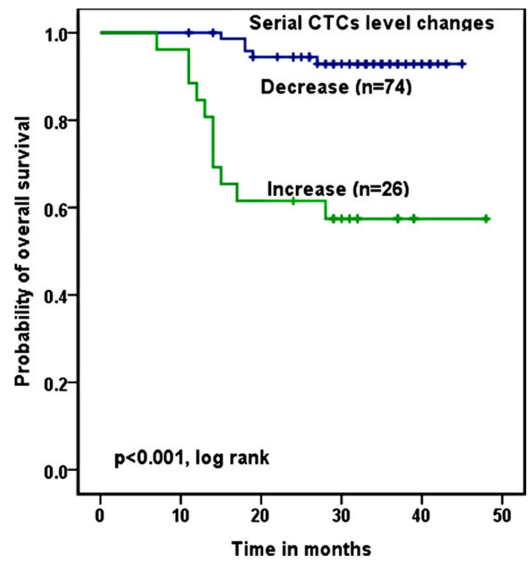

C

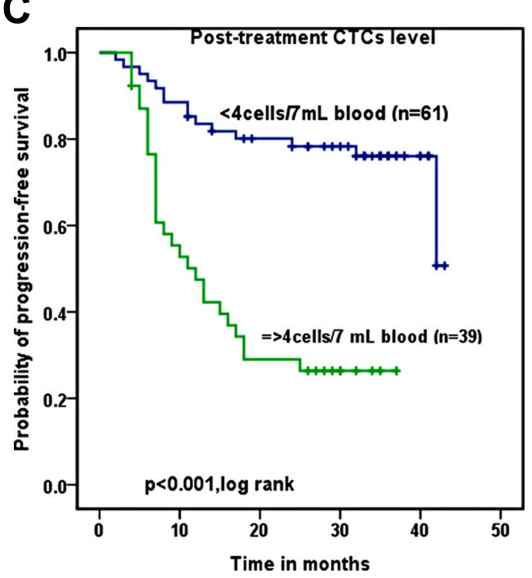

F

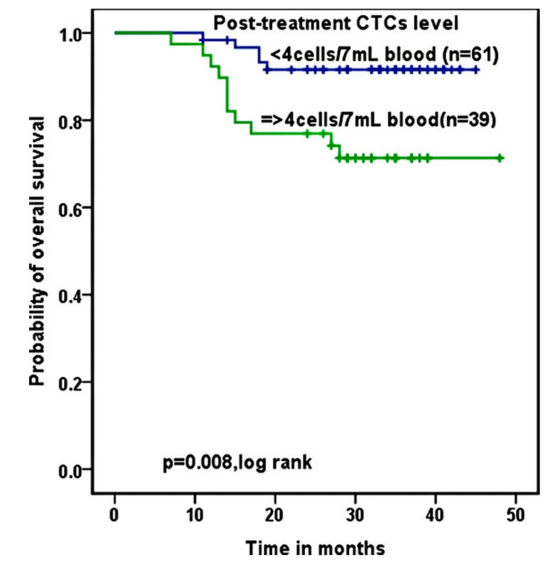

Figure 2 Association between PFS and (A) baseline CTCs count, (B) serial CTCs change, (C) post-treatment CTCs count. Association between OS and (D) baseline CTCs count, (E) serial CTCs change, (F) post-treatment CTCs count.

$(\mathrm{P}<0.012)$. Whereas distant metastasis $(\mathrm{P}<0.001), \mathrm{LN}$ metastasis $(\mathrm{P}=0.047)$, presence of $\mathrm{DM}(\mathrm{P}=0.05)$, posttreatment CTC levels $(\mathrm{P}=0.001)$, and serial CTCs level changes during the course of treatment $(\mathrm{P}<0.001)$ were independent prognostic factors for PFS (Table 5).

\section{Correlation Between MSI and CTCs Count (Baseline and Post-Treatment)}

There was a significant weak correlation between the presence of MSI and post-treatment CTCs count in CRC patients $(r h o=0.399, \mathrm{P}<0.001)$. However, there was no significant correlation between MSI and the baseline CTCs count in CRC patients (rho $=-0.11, \mathrm{P}=0.29$, Figure 4).

\section{Discussion}

In the last two decades, the detection of circulating tumor cells (CTCs) in the peripheral blood of CRC patients provided an important information about the tumor behavior and its metastases. Also, it helps physicians in guiding patients to the appropriate treatment. ${ }^{18}$ In the current study, we assessed the role of CTCs and its serial changes during the course of treatment as a diagnostic, prognostic and predictive biomarker for CRC patients. Our results demonstrated that increased PFS and OS rates were associated significantly with the count of post-treatment CTCs $(<4$ cells $/ 7 \mathrm{~mL}$ blood) and also with the decreased CTC levels during the course of treatment, while there was no significant association with the baseline CTC levels, though our previous work on non-metastatic CRC cases demonstrated that patients with baseline CTCs count $\geq 4$ cells had statistically reduced 5 years PFS and OS rates than those with CTCs count $<4$ cells. ${ }^{16}$ One possible explanation for this could be the current study dealt with all CRC (metastatic and non-metastatic) patients who attended the NCI during the assigned period. 


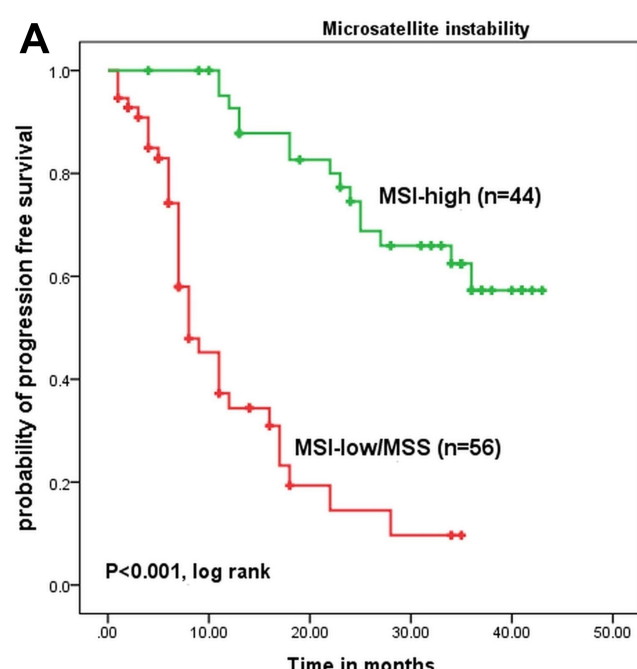

C

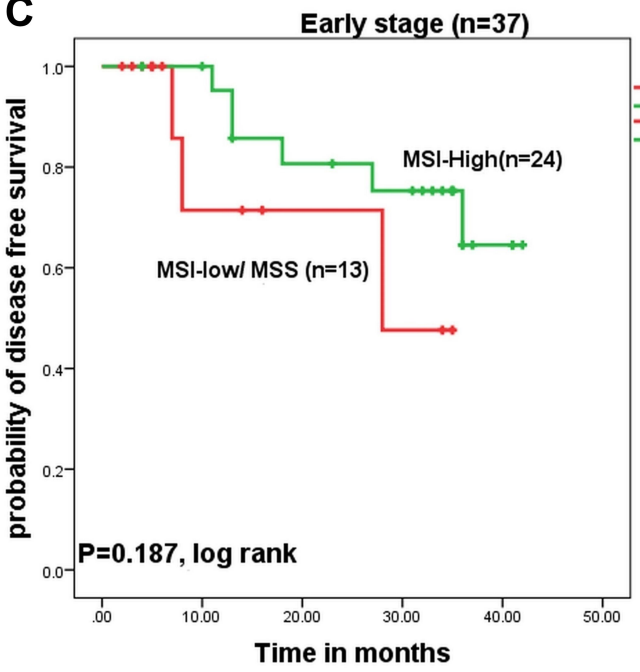

E

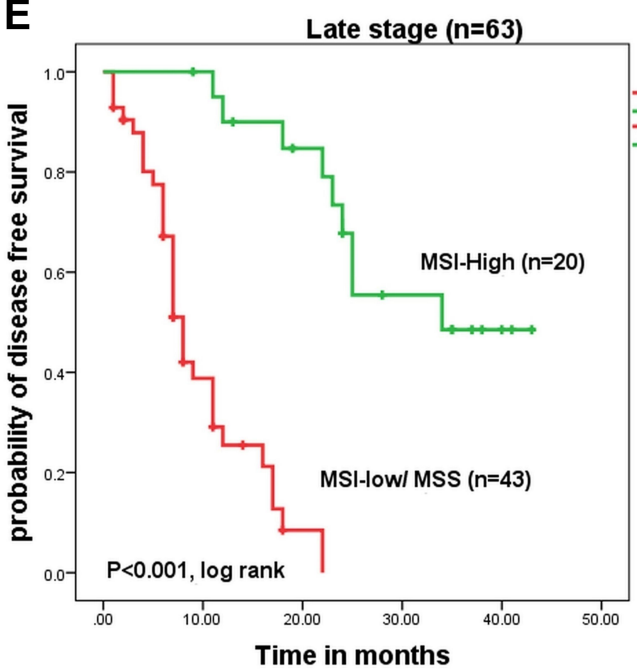

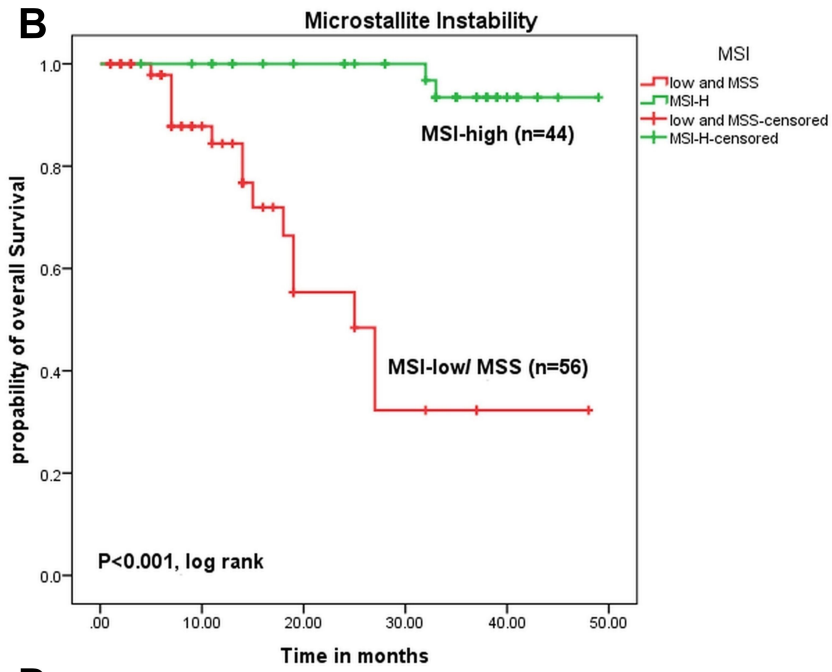

D
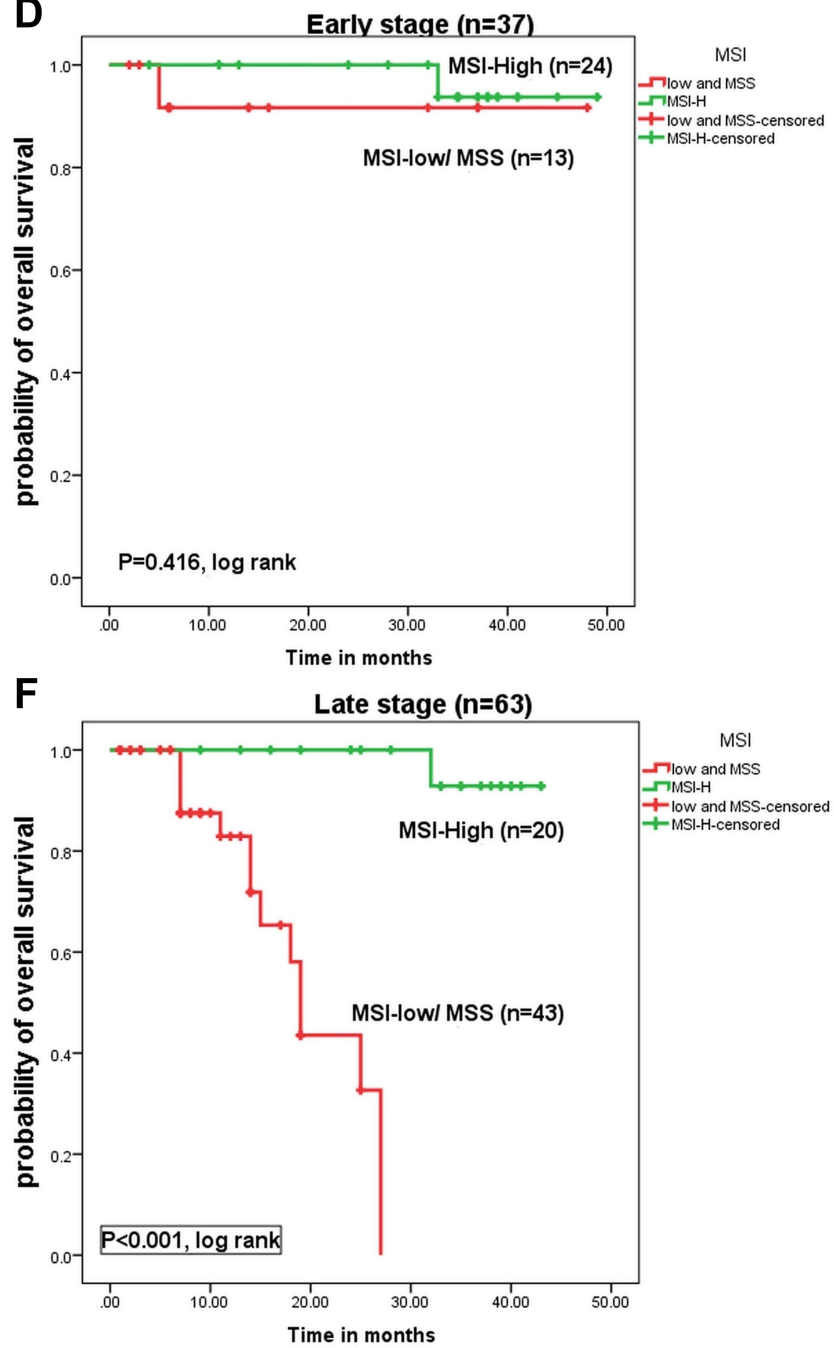

Figure 3 The impact of MSI levels in all CRC patients on (A) PFS and (B) OS rates. The impact of MSI levels in early-stage CRC patients on (C) PFS and (D) OS rates. The impact of MSI levels in late-stage CRC patients on (E) PFS and (F) OS rates.

The data reported in the current study are in concordance with that reported by Huang et al, ${ }^{19}$ and $\mathrm{Lu}$ et $\mathrm{al},{ }^{20}$ who demonstrated that the persistent presence of postoperative CTCs is a poor prognostic factor for patients with $\mathrm{CRC}$ after curative resection. In addition, Yang et $\mathrm{al}^{21}$ performed a meta-analysis report on 12 studies included 
Table 5 Univariate and Multivariate Survival Analysis for the Assessed CRC Patients

\begin{tabular}{|c|c|c|c|c|c|c|}
\hline \multirow[t]{2}{*}{ Parameters } & \multicolumn{3}{|c|}{ Overall Survival } & \multicolumn{3}{|c|}{ Progression-Free Survival } \\
\hline & HR & $95 \% \mathrm{Cl}$ & $\mathbf{p}$ & HR & $95 \% \mathrm{Cl}$ & $\mathbf{p}$ \\
\hline \multicolumn{7}{|l|}{ Univariate } \\
\hline $\begin{array}{l}\text { Age (years) } \\
\qquad 46 \text { vs } \geq 46\end{array}$ & 0.71 & $0.27-1.9$ & 0.50 & 1.01 & $0.60-2.0$ & 0.76 \\
\hline $\begin{array}{l}\text { Gender } \\
\text { Male vs Female }\end{array}$ & 2.6 & $0.94-7.1$ & 0.067 & 1.37 & $0.75-2.5$ & 0.31 \\
\hline $\begin{array}{l}\text { DM } \\
\text { Diabetic vs Non-diabetic }\end{array}$ & 1.04 & $0.24-4.6$ & 0.96 & 2.7 & $1.2-5.8$ & 0.012 \\
\hline $\begin{array}{l}\text { Hypertension } \\
\text { HTN vs non-HTN }\end{array}$ & 1.65 & $0.47-5.8$ & 0.44 & 1.5 & $0.7-3.3$ & 0.30 \\
\hline $\begin{array}{l}\text { FH } \\
\text { Yes vs No }\end{array}$ & 1.4 & $0.40-5.0$ & 0.58 & 1.4 & $0.67-3.1$ & 0.36 \\
\hline $\begin{array}{l}\text { Stage } \\
\text { Late vs Early }\end{array}$ & 9.6 & I.3-72.5 & 0.029 & 3.47 & $1.6-7.5$ & 0.002 \\
\hline $\begin{array}{l}\text { Grade } \\
\quad 3 \text { vs } I-2\end{array}$ & 3.01 & $1.13-8.0$ & 0.028 & 1.3 & $0.69-2.6$ & 0.39 \\
\hline $\begin{array}{l}\text { Metastasis } \\
\text { MI vs M0 }\end{array}$ & 5.0 & $1.8-13.7$ & 0.002 & 7.2 & $3.8-13.5$ & $<0.001$ \\
\hline $\begin{array}{l}\text { T stage } \\
\text { T3-4 vs TI-2 }\end{array}$ & 1.29 & $0.37-4.5$ & 0.69 & 0.58 & $0.30-1.2$ & 0.11 \\
\hline $\begin{array}{l}\text { LN } \\
\quad \text { Present vs Absent }\end{array}$ & 3.3 & $0.95-11.6$ & 0.06 & 2.0 & $1.03-3.8$ & 0.038 \\
\hline $\begin{array}{l}\text { MSI } \\
\text { High vs Low and stable }\end{array}$ & 2.9 & 1.19-7.2 & 0.019 & 1.6 & $1.04-2.05$ & 0.033 \\
\hline $\begin{array}{c}\text { Baseline CTCs Count } \\
\geq 4 \text { vs }<4 / 7 \mathrm{~mL} \text { blood }\end{array}$ & 0.46 & $0.17-1.2$ & 0.12 & 1.3 & $0.7-2.5$ & 0.39 \\
\hline $\begin{array}{l}\text { Post-Treatment CTCs Level } \\
\geq 4 \text { vs }<4 / 7 \mathrm{~mL} \text { blood }\end{array}$ & 3.8 & $1.3-10.9$ & 0.01 & 4.8 & $2.5-9.1$ & $<0.001$ \\
\hline $\begin{array}{l}\text { Serial CTCs Change Levels } \\
\text { Increase vs Decrease }\end{array}$ & 8.1 & $2.8-23.2$ & $<0.001$ & 6.8 & $3.5-12.9$ & $<0.001$ \\
\hline Multivariate & & & & & & \\
\hline $\begin{array}{l}\text { DM } \\
\text { Diabetic vs Non-diabetic }\end{array}$ & & & & 2.4 & $0.99-6.0$ & 0.05 \\
\hline $\begin{array}{l}\text { Hypertension } \\
\text { HTN vs Non-HTN }\end{array}$ & & & & 1.1 & $0.47-2.8$ & 0.89 \\
\hline $\begin{array}{l}\text { Stage } \\
\text { Late vs Early }\end{array}$ & 5.7 & $0.67-49.6$ & 0.11 & 3.3 & $0.99-10.8$ & 0.051 \\
\hline $\begin{array}{l}\text { Grade } \\
3 \text { vs I-2 }\end{array}$ & 2.3 & $0.79-6.4$ & 0.13 & & & \\
\hline
\end{tabular}


Table 5 (Continued).

\begin{tabular}{|c|c|c|c|c|c|c|}
\hline \multirow[t]{2}{*}{ Parameters } & \multicolumn{3}{|c|}{ Overall Survival } & \multicolumn{3}{|c|}{ Progression-Free Survival } \\
\hline & HR & $95 \% \mathrm{Cl}$ & $\mathbf{p}$ & HR & $95 \% \mathrm{Cl}$ & $\mathbf{p}$ \\
\hline \multicolumn{7}{|l|}{ Metastasis } \\
\hline MI vs M0 & 1.45 & $0.45-4.7$ & 0.54 & 3.9 & I.7-8.8 & 0.001 \\
\hline \multicolumn{7}{|l|}{$\mathbf{L N}$} \\
\hline Present vs Absent & & & & 2.6 & $\mathrm{I} .0 \mathrm{I}-7.04$ & 0.047 \\
\hline \multicolumn{7}{|l|}{ MSI } \\
\hline High vs Low and MSS & 1.87 & $0.7 I-4.9$ & 0.21 & 0.84 & $0.5 \mathrm{I}-\mathrm{I} .4$ & 0.50 \\
\hline Post-Treatment CTCs Level & & & & & & \\
\hline$\geq 4$ vs $<4 / 7 \mathrm{~mL}$ blood & 1.8 & $0.58-5.9$ & 0.30 & 3.6 & I.6-7.8 & 0.001 \\
\hline Serial CTCs Change Levels & & & & & & \\
\hline Increase vs Decrease & 4.1 & $1.26-13.5$ & 0.012 & 5.1 & $2.3-11.3$ & $<0.001$ \\
\hline
\end{tabular}

Note: Values in bold are statistically significant $<0.05$.

Abbreviations: CTCs, circulating tumor cells; MSI, microsatellite instability.

all patients who underwent colectomy for diseases staged I-III. They demonstrated that the presence of CTCs was strongly associated with both poor OS and DFS rates independently of the timing of specimen collection. Similarly, in another meta-analysis done by Rahbari et al, ${ }^{22}$ on 36 studies, they reported that the detection of CTCs was significantly correlated with poor prognosis in CRC patients when they were collected in peripheral blood rather than in mesenteric portal blood or bone marrow.

In a recent study done by Kaifi et $\mathrm{al}^{23}$ the authors concluded that the presence of high number of baseline CTCs in stage IV CRC patients was associated significantly with high tumor burden in the liver and high baseline serum CEA level, while there was no significant association with gender distribution, presence of metastases, primary CRC differentiation, tumor location, histology, tumor invasion depth, nodal status, or venous invasion. In agreement with these findings, our results revealed that the baseline CTCs count did not associate significantly with any of the assessed clinic-pathological features of the patients including age, gender, family history, presence of diabetes mellitus, hypertension, tumor stage, grade, pathological type, tumor site, distant or LN metastasis. However, with the follow-up of the patients,

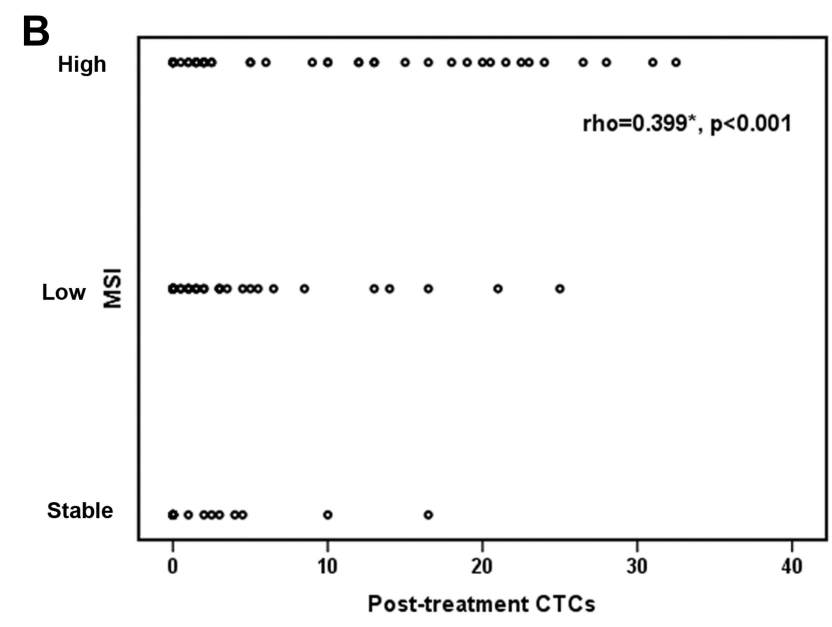

Figure 4 Correlation between MSI and CTCs count (Baseline and post-treatment). (A) Non-significant negative correlation between MSI-high and increase in number of base line CTCs (rho=-0.II, $\mathrm{p}=0.29$ ). $(\mathbf{B})$ shows significant positive correlation between MSI-high and increase in number of post-treatment $\mathrm{CTCs}$ (rho=0.399, $\mathrm{p}<0.00 \mathrm{I}$ ). Abbreviation: rho, Spearman's coefficient. 
we found that the increased CTCs count during the course of treatment was associated significantly with incidence of distant metastasis in these patients. On the contrary, Yang et $\mathrm{al}^{21}$ observed a significant association between the presence of CTCs and regional lymph nodes metastasis, depth of infiltration, vascular invasion, tumor grade and stage. Moreover, multivariate logistic regression analysis for our data showed that only serial CTCs level changes were independent prognostic factors for OS, while posttreatment CTC levels, serial CTCs level changes during the course of treatment, presence of DM, LN and distant metastasis were independent prognostic factors for PFS, however the presence of DM was of borderline significance. Therefore, our results indicated that the assessment of CTCs during and at the end of treatment is more accurate and sensitive marker for prediction of patients' prognosis and outcomes rather than the baseline CTCs count. These data are in agreement with that reported by Huang et $\mathrm{al}^{24}$ who conducted a meta-analysis on 11 studies containing 1847 CRC patients from China. Similarly, they concluded that early detected CTCs did not associate with the survival outcomes, because a portion of the earlydetected CTCs can be cleared by the effects of chemotherapy, and so they will not affect the prognosis of the patients. Serial samples obtained during follow-up of the patients might contain additional CTCs that have been released from the primary tumor after changes in the tumor proliferative activity. ${ }^{25,26}$

An important molecular marker that has a good prognostic and predictive value for CRC is the MSI. Our data revealed a high frequency of MSI-high in $44.0 \%$ of the patients, followed by MSI-low in 37\% of the patients and MSS in only $19.0 \%$ of the assessed CRC patients. The incidence of MSI-high was associated significantly with the early (I-II) disease stage, while MSI-low was associated significantly with the late (IV) disease stage. Moreover, patients with MSI-high tumors had a significantly lower incidence of LN and distant metastasis compared to those with MSI-low/MSS tumors which were associated significantly with positive LN and distant metastasis. These results are in agreement with a recent published data ${ }^{27-30}$ reported that MSI-high occurs more frequently in early pathological stage than late-disease stage, and consequently reduced chance of distant and nodal metastasis. According to our data, there was no significant association between the incidence of MSI and other clinic-pathological features of the patients including age, gender, family history, hypertension, tumor pathology, grade, or site. However, several studies showed that MSI was associated with more proximal location, mucinous phenotype and high histological grade. ${ }^{30-32}$ Moreover, Nakayama et $\mathrm{al}^{33}$ reported that the incidence of DM (type II) was significantly less frequent in MSI-H compared with MSS and MSI-low in Japanese CRC patients. On the other side, our results showed a significant association between the presence of DM and reduced PFS, but we did not find a significant association with MSI. This discrepancy in data could be attributed, at least in part, to the variation in the genetic backgrounds, dietary habits, and different life style between the two populations.

We also found that patients with MSI-high had significantly higher PFS and OS rates compared to those with MSI-low and MSS. In addition, these data were also applied to patients in late disease stage. These results are in agreement with previous studies which demonstrated a better prognosis and lower recurrence risk in MSI-H CRC patients with pathologic stage II tumors compared to MSS/MSI-L CRC patients. ${ }^{34-36}$ Moreover, Battaglin et $\mathrm{al}^{37}$ reported a significant association between MSIhigh and better prognosis in early-stage CRC patients and a lack of benefit from adjuvant treatment with 5-fluorouracil in stage II disease. On the contrary, a recent study done by Kim et $\mathrm{al}^{38}$ demonstrated that in stage II, MSI-H was associated with poor prognosis and reduced 3-year survival rates compared to those with MSS and MSI-L CRCs. In addition, the multivariate analysis of their results provided additional evidence that MSI-H status could be considered a poor independent prognostic marker for CRC patients. On the contrary, Mohan et $\mathrm{al}^{30}$ and Gelsomino et $\mathrm{al}^{27}$ reported that MSI was associated with an improved PFS in Stage I/II CRC. However, when MSI tumours progress to Stage III these patients had worse outcomes and poor pathological features due to possible resistance to 5 -FU in these patients.

The current data showed that MSI was not an independent predictor for OS or PFS rates. These data are in agreement with Chong et al, ${ }^{39}$ who reported that MSI was not an independent prognostic factor for OS in patients with metastatic CRC from South Australia.

Furthermore, another result in the current study was the significant weak correlation detected between the presence of MSI-high in CRC patients and the post-treatment CTCs count in those patients, which indicate that both markers have important roles in the pathogenesis and prognosis of colorectal carcinoma. 
Based on our previously mentioned discussion, we conclude that MSI and CTCs, either separately or combined, could be used as accurate, reliable and sensitive diagnostic and prognostic biomarkers for CRC patients' survival rates and outcomes. Especially that nowadays, the treatment of CRC patients depends to a large extent on the MSI status, but if we have to choose one of them, MSI is more accurate, informative and related to treatment giving. Meanwhile, CTCs are rather important for prognosis and prediction of patients' survival, but it is not yet included in the guidelines, and still need confirmation in larger studies. Therefore, further studies, on a larger population are still needed to 1) assess the possible use of CTCs as a guidance for future therapy for these patients, and 2) to compare between those two biological markers in Egypt and other countries regarding the frequency, patterns and impact on patients' outcome.

\section{Funding}

This manuscript has been financially supported by the National Cancer Institute, Cairo University.

\section{Disclosure}

Dr Aya Alsayed reports grants from Cairo University during the conduct of the study. The authors report no other potential conflicts of interest for this work.

\section{References}

1. Torre LA, Bray F, Siegel RL, Ferlay J, Lortet-Tieulent J, Jemal A. Global cancer statistics, 2012. CA Cancer J Clin. 2015;65:87-108. doi: $10.3322 /$ caac. 21262

2. Howlader N, Noone AM, Krapcho M, et al. SEER Cancer Statistics Review, 1975-2017. Bethesda, MD: National Cancer Institute. Available from: https://seer.cancer.gov/csr/1975_2017/.

3. Graham JS, Cassidy J. Adjuvant therapy in colon cancer. Expert Rev Anticancer Ther. 2012;12:99-109. doi:10.1586/era.11.189

4. Hammond WA, Swaika A, Mody K. Pharmacologic resistance in colorectal cancer: a review. Ther Adv Med Oncol. 2016;8:57-84. doi: $10.1177 / 1758834015614530$

5. Kievit J, Bruinvels DJ. Detection of recurrence after surgery for colorectal cancer. Eur J Cancer. 1995;31A:1222-1225. doi:10.1016/09598049(95)00155-C

6. Siravegna G, Marsoni S, Siena S, Bardelli A. Integrating liquid biopsies into the management of cancer. Nat Rev Clin Oncol. 2017;14 (9):531. doi:10.1038/nrclinonc.2017.14

7. Alix-Panabieres C, Pantel K. Challenges in circulating tumour cell research. Nat Rev Cancer. 2014;14(9):623-631. doi:10.1038/nrc3820

8. Cohen SJ, Punt CJ, Iannotti N, et al. Relationship of circulating tumor cells to tumor response, progression-free survival, and overall survival in patients with metastatic colorectal cancer. Clin Oncol. 2008;26:3213-3221.
9. Cristofanilli M. Circulating tumor cells, disease progression, and survival in metastatic breast cancer. InSeminars Oncol. 2006;33:9-14. WB Saunders.

10. De Bono JS, Scher HI, Montgomery RB, et al. Circulating tumor cells predict survival benefit from treatment in metastatic castration-resistant prostate cancer. Clin Cancer Res. 2008;14 (19):6302-6309. doi:10.1158/1078-0432.CCR-08-0872

11. Ribeiro-Samy S, Oliveira MI, Pereira-Veiga T, et al. Fast and efficient microfluidic cell filter for isolation of circulating tumor cells from unprocessed whole blood of colorectal cancer patients. Sci Rep. 2019;9(1):8032. doi:10.1038/s41598-019-44401-1

12. Ward R, Meagher A, Tomlinson I, et al. Microsatellite instability and the clinicopathological features of sporadic colorectal cancer. Gut. 2001;48:821-829. doi:10.1136/gut.48.6.821

13. Shia J. Immunohistochemistry versus microsatellite instability testing for screening colorectal cancer patients at risk for hereditary nonpolyposis colorectal cancer syndrome: part I. The utility of immunohistochemistry. $J$ Mol Diagn. 2008;10(4):293-300. doi: $10.2353 /$ jmoldx.2008.080031

14. Zeinalian M, Hashemzadeh-Chaleshtori M, Salehi R, Emami MH. Clinical aspects of microsatellite instability testing in colorectal Cancer. Adv Biomed Res. 2018;7:7. doi:10.4103/abr.abr_185_16

15. Zarkavelis G, Boussios S, Papadaki A, Katsanos KH, Christodoulou DK, Pentheroudakis G. Current and future biomarkers in colorectal cancer. Ann Gastroenterol. 2017;30(6):613-621. doi:10.20524/aog.2017.0191

16. Bahnassy AA, Salem SE, Mohanad M, et al. Prognostic significance of circulating tumor cells (CTCs) in Egyptian non-metastatic colorectal cancer patients: a comparative study for four different techniques of detection (Flowcytometry, CellSearch, Quantitative Real-time PCR and Cytomorphology). Exp Mol Pathol. 2019;106:90-101. doi:10.1016/j.yexmp.2018.12.006

17. Zekri AN, Khaled HM, Mohammed MB, et al. Microsatellite instability profiling in Egyptian bladder cancer patients: a pilot study. Curr Probl Cancer. 2019;43(6):100472. doi:10.1016/j. currproblcancer.2019.03.002

18. Scripcariu V, Scripcariu DV, Filip B, Gavrilescu MM, Muşină AM, Volovăţ C. " Liquid Biopsy"-Is it a Feasible Option in Colorectal Cancer? Chirurgia. 2019;114(2):162-166. doi:10.21614/ chirurgia.114.2.162

19. Huang MY, Tsai HL, Huang JJ, Wang JY. Clinical implications and future perspectives of circulating tumor cells and biomarkers in clinical outcomes of colorectal cancer. Transl Oncol. 2016;9 (4):340-347. doi:10.1016/j.tranon.2016.06.006

20. Lu CY, Uen YH, Tsai HL, et al. Molecular detection of persistent postoperative circulating tumour cells in stages II and III colon cancer patients via multiple blood sampling: prognostic significance of detection for early relapse. Br J Cancer. 2011;104(7):1178-1184. doi:10.1038/bjc. 2011.40

21. Yang C, Zou K, Zheng L, Xiong B. Prognostic and clinicopathological significance of circulating tumor cells detected by RT-PCR in non-metastatic colorectal cancer: a meta-analysis and systematic review. BMC Cancer. 2017;17(1):725. doi:10.1186/s12885-0173704-8

22. Rahbari NN, Aigner M, Thorlund K, et al. Meta-analysis shows that detection of circulating tumor cells indicates poor prognosis in patients with colorectal cancer. Gastroenterology. 2010;138 (5):1714-1726. doi:10.1053/j.gastro.2010.01.008

23. Kaifi JT, Kunkel M, Dicker DT, et al. Circulating tumor cell levels are elevated in colorectal cancer patients with high tumor burden in the liver. Cancer Biol Ther. 2015;16(5):690-698. doi:10.1080/ 15384047.2015.1026508

24. Huang X, Gao P, Song Y, et al. Meta-analysis of the prognostic value of circulating tumor cells detected with the CellSearch System in colorectal cancer. BMC Cancer. 2015;15(1):202. doi:10.1186/s12885015-1218-9 
25. Molnar B, Sipos F, Galamb O, Tulassay Z. Molecular detection of circulating cancer cells. Role in diagnosis, prognosis and follow-up of colon cancer patients. Dig Dis. 2003;21(4):320-325. doi:10.1159/ 000075355

26. Lim SH, Becker TM, Chua W, et al. Circulating tumour cells and circulating free nucleic acid as prognostic and predictive biomarkers in colorectal cancer. Cancer Lett. 2014;346(1):24-33. doi:10.1016/j. canlet.2013.12.019

27. Gelsomino F, Barbolini M, Spallanzani A, Pugliese G, Cascinu S. The evolving role of microsatellite instability in colorectal cancer: a review. Cancer Treat Rev. 2016;51:19-26. doi:10.1016/j. ctrv.2016.10.005

28. Roth AD, Tejpar S, Delorenzi M, et al. Prognostic role of KRAS and BRAF in stage II and III resected colon cancer: results of the translational study on the PETACC-3, EORTC 40993, SAKK 60-00 trial. J Clin Oncol. 2010;28:466-474. doi:10.1200/JCO.2009.23.3452

29. Koopman M, Kortman GA, Mekenkamp L, et al. Deficient mismatch repair system in patients with sporadic advanced colorectal cancer. $\mathrm{Br}$ $J$ Cancer. 2009;100(2):266-273. doi:10.1038/sj.bjc.6604867

30. Mohan HM, Ryan E, Balasubramanian I, et al. Microsatellite instability is associated with reduced disease specific survival in stage III colon cancer. Eur J Surg Oncol. 2016;42(11):1680-1686. doi:10.1016/j.ejso.2016.05.013

31. Srdjan M, Jadranka A, Ivan D, et al. Microsatellite instability \& survival in patients with stage II/III colorectal carcinoma. Indian $J$ Med Res. 2016;143(Suppl 1):S104. doi:10.4103/0971-5916.191801

32. Dubey AP, Vishwanath S, Nikhil P, Rathore A, Pathak A. Microsatellite instability in stage II colorectal cancer: an Indian perspective. Indian J Cancer. 2016;53(4):513. doi:10.4103/0019509X.204772
33. Nakayama Y, Iijima T, Wakaume R, et al. Microsatellite instability is inversely associated with type 2 diabetes mellitus in colorectal cancer. PLoS One. 2019;14(4):e0215513. doi:10.1371/journal. pone. 0215513

34. Benatti P, Gafà R, Barana D, et al. Microsatellite instability and colorectal cancer prognosis. Clin Cancer Res. 2005;11 (23):8332-8340. doi:10.1158/1078-0432.CCR-05-1030

35. Guastadisegni C, Colafranceschi M, Ottini L, Dogliotti E. Microsatellite instability as a marker of prognosis and response to therapy: a meta-analysis of colorectal cancer survival data. Eur $J$ Cancer. 2010;46(15):2788-2798. doi:10.1016/j.ejca.2010.05.009

36. Müller CI, Schulmann K, Reinacher-Schick A, et al. Predictive and prognostic value of microsatellite instability in patients with advanced colorectal cancer treated with a fluoropyrimidine and oxaliplatin containing first-line chemotherapy. A report of the AIO Colorectal Study Group. Int $J$ Colorectal Dis. 2008;23 (11):1033-1039. doi:10.1007/s00384-008-0504-2

37. Battaglin F, Naseem M, Lenz HJ, Salem ME. Microsatellite instability in colorectal cancer: overview of its clinical significance and novel perspectives. Clin Adv Hematology Oncol. 2018;16 (11):735-745.

38. Kim NK. Is a microsatellite instability still useful for tailored treatment in stage II and III colon cancer? Ann Coloproctol. 2014;30:5-6. doi:10.3393/ac.2014.30.1.5

39. Chong LC, Townsend AR, Young J, et al. Outcomes for metastatic colorectal cancer based on microsatellite instability: results from the south australian metastatic colorectal cancer registry. Target Oncol. 2019;14(1):85-91. doi:10.1007/s11523-018-0615-9
OncoTargets and Therapy

\section{Publish your work in this journal}

OncoTargets and Therapy is an international, peer-reviewed, open access journal focusing on the pathological basis of all cancers, potential targets for therapy and treatment protocols employed to improve the management of cancer patients. The journal also focuses on the impact of management programs and new therapeutic agents and protocols on patient perspectives such as quality of life, adherence and satisfaction. The manuscript management system is completely online and includes a very quick and fair peer-review system, which is all easy to use. Visit http://www.dovepress.com/ testimonials.php to read real quotes from published authors 